International Journal of Agriculture, Environment and Bioresearch

Vol. 4, No. 06; 2019

ISSN: $2456-8643$

\title{
AREAS WITH POTENTIAL AGROECOLOGICAL FOR THE CULTURE OF Ricinus communis L. IN THE STATE OF CHIAPAS, MEXICO
}

\author{
Nestor Espinosa-Paz ${ }^{1}$. Rafael Ariza-Flores ${ }^{2}$, Jesus Martinez-Sanchez ${ }^{1}$ and Pedro Cadena-Iniguez ${ }^{1}$ \\ ${ }^{1}$ Researchers of Experimental Field Center of Chiapas, National Institute of Forestry, Agricultural and Livestock \\ Research. Km 3 Ocozocoautla-Cintalapa International Road, Chiapas, México \\ ${ }^{2}$ Researcher of Experimental Field Iguala. National Institute of Forestry, Agricultural and Livestock Research. \\ Iguala, Guerrero, México.
}

http://doi.org/10.35410/IJAEB.2019.4471

\begin{abstract}
Ricinus communis L. is a species native to Africa and its importance lies in the multiple uses of oil extracted from its seeds. The objective of this study was to determine the areas with agroecological potential for the cultivation of Ricinus communis in the state of Chiapas. It was carried out in three stages: the first was to determine the agroecological requirements of Ricinus communis L., through a literature review and field trips. The second one consisted of the climatic characterization using the database of the National Environmental Information System (SNIA) of the INIFAP in the period 1961-2003, of National Water Comission (CONAGUA) and of the Federal Electricity Commission (CFE). The third consisted of generating raster and shape stratified images of each climatic variable. The results indicate that it has an area of 1'579,939 hectares with good potential and represents $21.5 \%$ of the total area of the state. In total for these two Rural Development Districts of the Ministry of Agriculture and Rural Development (DDR), 893,482 hectares with high agroecological potential are estimated and represent $56 \%$ of the total state area.
\end{abstract}

Keywords: Agroecological areas, Ricinus communis L., Chiapas, Mexico.

\section{INTRODUCTION}

Ricinus communis $\mathrm{L}$. is a species that belongs to the Euphorbiaceae family and is reported to be native to Africa, from where it spread to the Middle East (Moncín, 2008). More than 4000 years ago the Egyptians used it in the lighting or lighting of their houses, it seems that it was a highly esteemed plant because in some Egyptian tombs their seeds have been found (Moncín 2008). This same author points out that in India and China this species was known about 3000 years ago and was probably introduced in America after its discovery. It is a shrub that adapts to tropical and subtropical climates around the world and, especially in areas with low rainfall and lightly textured soils, with low fertility and $\mathrm{pH}$ between 5.5 to 6.5 (Arango, 1990 cited by Moncín, 2008; Samayoa, 2007). In the Asian continent and in the countries of India, Brazil, Colombia, Uruguay, Peru, among others, this species is grown commercially with all the technical standards of modern agriculture (EMBRAPA, 2004; Moncín, 2008; Miranda, 2011). The crop has spread throughout the world, because its oil is used as a lubricant because of its high density, because it retains its viscosity at different temperatures and because it only freezes at $10^{\circ} \mathrm{C}$ below zero 
(Arango, 1990, cited by Moncín, 2008). In addition, it is used in industrial products such as crayons, packaging, enamels, paint emulsion, fertilizers, foams, shock absorber fluid, hydraulic fluid due to its high density, fungicides, fats, rubber, insecticides, lacquers, coating materials, putty for glass, carbon paper, flypaper, packing paste, polyesters, pharmaceuticals, polishers, paper coating, printing inks, candles, among others (EMBRAPA. 2004). Recently it has been determined that Ricinus communis L. oil has good physical and chemical characteristics for the production of biodiesel and bioturbocin or biokerosene (Miranda, 2012) and is a species that is not important for the human diet and has prospects for development commercially in many countries of the world including Mexico. Its use as a biofuel has a great advantage, because it reduces environmental pollution to zero because it is the only alternative fuel that can be used in any diesel engine, without requiring any modification (Miranda, 2011).

In Mexico, it is grown on a small scale in the states of Oaxaca, Michoacán and Guanajuato. As of 2014 in the states of Sinaloa, Sonora and Tamaulipas, the Biofields company has established higuerilla sowings using improved genotypes under drip fertirrigation using a waistband and in 2014 they installed an oil extraction plant in the municipality of Navojoa, Sonora in northern Mexico, with the purpose of exporting it to Europe (personal communication of Biofields Company executives).

In the state of Chiapas, it is generally considered a weed and its habitat is naturally in public garbage dumps, in some places on the banks of roads and rivers, in the courtyards of some rural houses and in vacant sites of urban areas. Due to the importance of Ricinus oil for the production of biodiesel and bioturbocin, in 2008, in the Experimental field of Rosarios Izapa of INIFAP, research on this species was initiated, through the establishment of approximately 350 collections made in the Mexican Republic, with the purpose of selecting genotypes of good grain yield and high oil content in the grain. On the other hand, studies were conducted on production technologies. In the state of Guanajuato, in 2017 the Guanajuato Oil variety was released and the release of the Mex-Oil variety is in process. To succeed in establishing the crop, it is necessary to delimit the areas with good agroecological potential. The objective of the present investigation was to determine the areas with agroecological potential for the cultivation of Ricinus communis L. in the state of Chiapas.

\section{MATERIALS AND METHODS}

The study was conducted in the state of Chiapas, which has an area of 7.33 million hectares. Warm humid and subhumid, semi-warm and temperate climates predominate. Precipitation ranges from 700 to 4,000 $\mathrm{mm}$ per year. The types of soils that predominate are cambisol, regosol, vertisol, rendzinas, feozem, among others. The delimitation of the areas with agroecological potential was carried out through the following three stages (Reynoso, 2012; Díaz et al., 2012): The first was to determine the agroecological requirements of Ricinus communis L., through bibliographic review and field trips. The second one consisted of the climatic characterization using the database of the National Environmental Information System (SNIA) of the INIFAP in the period 1961-2003, of National Water Comission (CONAGUA) and of the CFE (Serrano et al., 2006). Calculations were made of annual average maximum temperature, annual average 
minimum, annual average, annual average daytime, annual average night, accumulated precipitation, accumulated evaporation and potential evapotranspiration. For the edaphic characterization the digitized information of the edaphic charts and units of soils of the National Institute of Statistics, Geography and Informatics. The topographic characterization of the INEGI Digital Elevation Model was acquired. The third stage consisted of the zoning of the areas with agroecological potential from the comparative analysis of the information of ecological requirements of the cultivation of higuerilla, the raster and shape stratified images were generated of each climatic, edaphic and physiographic variable, with the ranges of ecological and agronomic management requirements to delimit the potential agro-ecological zones (optimal, suboptimal and marginal). For this, the Geographic Information System (GIS) IDRISI and Arc Gis $9.2 \odot$, were used with the techniques of superposition of stratified images and map algebra (Díaz, 2012, Reynoso, 2012). As a result of the interactions of the climatic, edaphic and topographic variables, the final map was obtained with agroecological potentials with the optimal, sub-optimal and marginal classifications for the cultivation of Ricinus at the state level. In this phase, the INEGI 1: 250000 Series III Land and Vegetation Use letter was used to discard areas with forest use, urban areas, human settlements and water bodies, to keep areas useful for cultivation

\section{RESULTS AND DISCUSSION}

Agro ecological requirements for Ricinus. The optimum altitude varies from 7 to 1800 meters above sea level. The optimum temperature varies from 19 to $30^{\circ} \mathrm{C}$. The optimal rainfall varies from 400 to $1000 \mathrm{~mm}$ per year. The optimal slope varies from 7 to $15 \%$. The optimal soil type is Regosol, although it can thrive in the Cambisol and Feozem types. (Arango, 1990 cited by Moncín, 2008; Samayoa, 2007; Moncin, 2008; Díaz et al., 2012; Miranda, 2011).

Agroecological characterization of the state of Chiapas. The optimal temperatures for the cultivation of Ricinus vary from 19 to $30^{\circ} \mathrm{C}$ and are recorded in the area of influence of the DDRs of Tapachula, Tonalá, Villaflores, Tuxtla, Comitán, Palenque and Selva. In the Tuxtla DDR, parts of Villaflores and Comitán, adequate rainfall is recorded for the cultivation of fig trees. The optimal slope (2 to 15\%) are distributed in all the DDRs of the state. The optimal soil type is Regosoles and this can be found in greater proportion in the DDRs of Tuxtla, Comitán, Villaflores, Pichucalco and Palenque.

Areas with agroecological potential. In Figure 1, the surfaces for the category of optimal (high), suboptimal (medium) and marginal (low) for fig cultivation are presented. In the first category there is an area of $1 ' 579,939$ hectares and they represent $21.5 \%$ of the total area of the state. In the second, it has an area of 1'395 321 (19\% of the total area). In the category of low (marginal) potential, there are 379347.92 hectares (5\% of the total area). In all SADER DDRs in the state, areas with optimal potential for fig cultivation are observed, with the exception of Tapachula and Tonalá DDRs. The DDR 01 Tuxtla has an area of 387,977 hectares with optimal potential and represents $24 \%$ of the state's surface, while DDR 04 Villaflores has 505,505 hectares and represents 32\%. In total for these two DDRs, 893482 hectares with high agroecological potential are estimated, which represents $56 \%$ of the total area of high potential estimated for the state (Figure 1). 


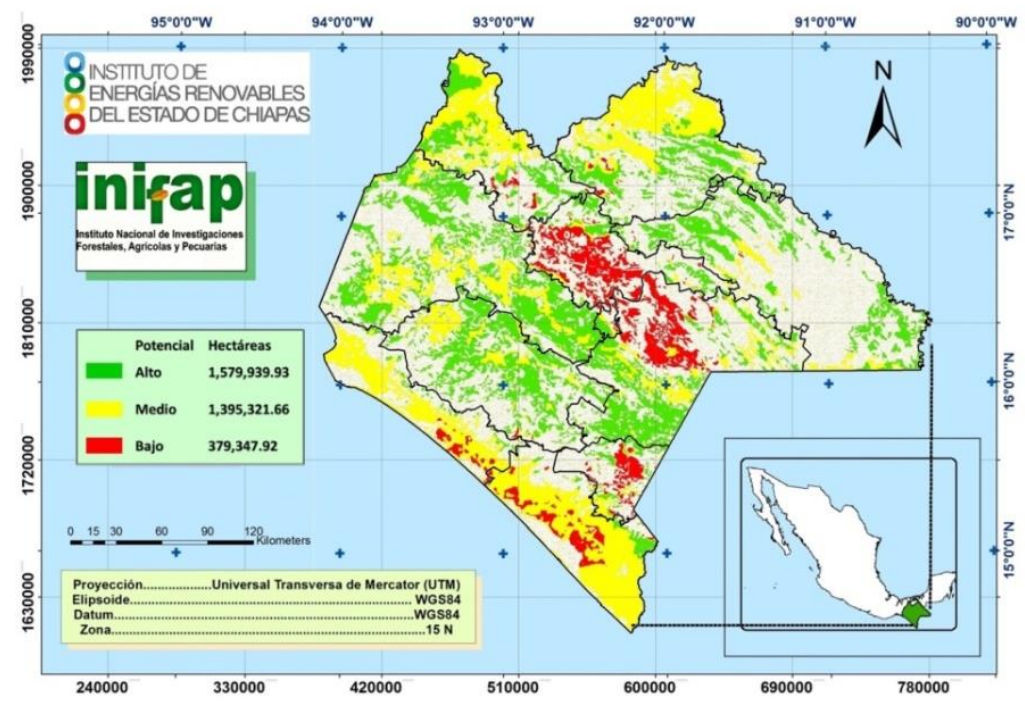

Figure 1. Potential areas for fig cultivation (Ricinus communis L.) for the state of Chiapas. Source: INIFAP 2016.

In these types of studies, the use of the Geographic Information System (GIS) stands out, which are made up of software and hardware whose purpose is to process the spatial information that is finally presented in tabular format and on maps (Boistad, 2005, cited by Díaz et al., 2012.). Agroecological zoning is a useful tool in the implementation of a productive agriculture with less risk and environmental impact, since the production of a crop in favorable environmental conditions lowers production technology and increases yield, crop quality and consequently, it improves the economy of the product, and the well-being of your family.

Figure 2 shows the spatial distribution of areas with optimal, suboptimal and marginal agroecological potential for the area of influence of the DDR 01 Tuxtla and 04 Villaflores. In this same figure and in figure 8, it is observed that DDR 01 Tuxtla has an area of 387,977 hectares with optimal potential and represents $24 \%$ of the state's surface, while DDR 04 Villaflores has 505505 hectares and represents 32\% In total for these two DDRs, 893482 hectares with high agroecological potential are estimated, which represents $56 \%$ of the total area of high potential estimated for the state.

Table 1 shows the optimal, sub-optimal and marginal area for each of the municipalities that make up DDR 01 Tuxtla. In this same table, it can be seen that the municipalities with the largest area are: Cintalapa with 48548 hectares with optimal agroecological potential, Chiapa de Corzo with 20 589, Jiquipilas with 26 979, Ocozocoautla with 45779 and Tepactán with 45195 hectares. 


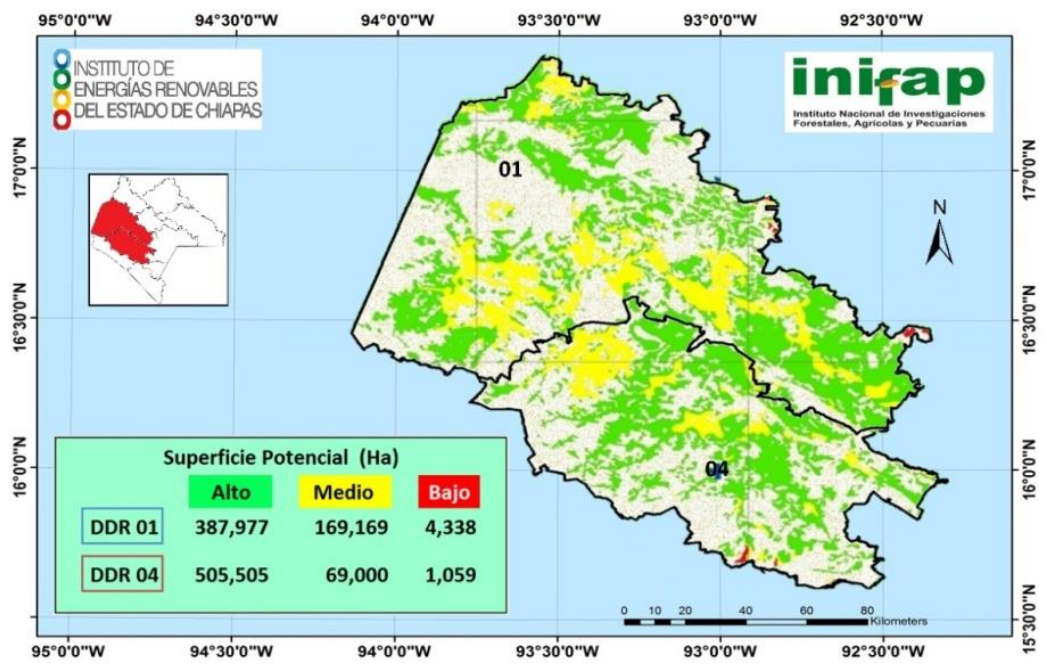

Figure 2 Potential areas for the cultivation of fig trees (Ricinus communis L.) the area of influence of the DDR 01 Tuxtla and 04 Villaflores. Source: INIFAP 2016.

Table 1. Area (ha) with productive potential for the municipalities of DDR 01 Tuxtla. INIFAP, MEXICO, 2016.

\begin{tabular}{|l|l|l|l|l|}
\multirow{2}{*}{ No. } & \multirow{2}{*}{ Municipality } & \multicolumn{3}{|l|}{ Area (ha) by type of potential } \\
\cline { 3 - 5 } & & HIGH & MEDIUM & LOW \\
\hline 002 & Acala & 21136 & 8048 & 0 \\
\hline 012 & Berriozábal & 11207 & 2979 & 0 \\
\hline 017 & Cintalapa & 48548 & 29149 & 0 \\
\hline 018 & Coapilla & 2111 & 0 & 0 \\
\hline 021 & Copainalá & 12766 & 0 & 0 \\
\hline 027 & $\begin{array}{l}\text { Chiapa } \\
\text { Corzo }\end{array}$ & 20587 & 24453 & 0 \\
\hline 028 & Chiapilla & 2686 & 1516 & 0 \\
\hline 029 & Chicoasen & 7555 & 0 & 0 \\
\hline 044 & Ixtapa & 8558 & 345 & 4338 \\
\hline 046 & Jiquipilas & 26979 & 31186 & 0 \\
\hline 058 & Nicolás Ruiz & 2042 & 0 & 0 \\
\hline 060 & Ocotepec & 0 & 0 & 0 \\
\hline 061 & Ocozocoautla & 45779 & 26695 & 0 \\
\hline 063 & Osumacinta & 16733 & 6235 & 0 \\
\hline
\end{tabular}




\begin{tabular}{|l|l|l|l|l|}
\hline 079 & San Fernando & 14882 & 769 & 0 \\
\hline 085 & Soyaló & 3498 & 209 & 0 \\
\hline 086 & Suchiapa & 9895 & 4399 & 0 \\
\hline 092 & Tepactán & 45191 & 17266 & 0 \\
\hline 098 & Totolapa & 6615 & 6450 & 0 \\
\hline 101 & $\begin{array}{l}\text { Tuxtla } \\
\text { Gutiérrez }\end{array}$ & 5829 & 5613 & 0 \\
\hline & TOTAL & $\mathbf{3 8 7 9 7 7}$ & $\mathbf{1 6 9 1 6 9}$ & $\mathbf{4 3 3 8}$ \\
\hline
\end{tabular}

For Villaflores DDR, Table 2 shows the estimated areas for the three types of agro-ecological potential. It is observed that the municipalities with the greatest area with optimal potential are: Villaflores with 123603 hectares, Villa Corzo with 190397 and La Concordia with 173303 hectares.

Table 2. Area (ha) with productive potential for the municipalities of the DDR 04 Villaflores. INIFAP, MEXICO, 2016

\begin{tabular}{|c|c|c|c|c|}
\hline \multirow[b]{2}{*}{ No. } & \multirow[b]{2}{*}{ Municipality } & \multicolumn{3}{|c|}{ Area (ha) by type of potential } \\
\hline & & High & Medium & Low \\
\hline 008 & $\begin{array}{l}\text { Ángel Albino } \\
\text { Corzo }\end{array}$ & 15449 & 1048 & $\mathrm{O}$ \\
\hline 107 & Villa Corzo & 190397 & 15655 & 0 \\
\hline 108 & Villaflores & 123603 & 92318 & 0 \\
\hline 117 & Monte Cristo & 2753 & 147 & 53 \\
\hline 020 & La Concordia & 173303 & 9833 & 1006 \\
\hline & TOTAL & 505503 & 69000 & 1059 \\
\hline
\end{tabular}

Agroecological zoning is the division of the earth's surface into smaller units with characteristics as similar or homogeneous as possible, in relation to their aptitude and potential production. The detail of these studies depends on their scale and sometimes the equipment used to process the information. The essential elements that define an agroecological zone are the period of growth, the regime of temperature, precipitation, slope and the soil unit (FAO, 1996). In these types of studies, the use of the Geographic Information System (GIS) stands out, which are made up of software and hardware that are intended to process spatial information and information that are finally presented in tabular format and on maps (Boistad, 2005, cited by Díaz et al., 2012).

Agroecological zoning is a useful tool in the implementation of a productive agriculture with less risk and environmental impact, since the production of a crop in favorable environmental conditions lowers production technology and increases yield, crop quality and consequently, it 
improves the economy of the product, and the well-being of his family, as indicated by Ruiz et al., (1999).

Field trips conducted by the state to observe the distribution of higuerilla (Ricinus communis L.) and its habitat, indicated that it has a wide distribution. We find it from sea level in the DDR Tapachula to 2,400 meters above sea level in the DDR San Cristóbal. It grows in garbage dumps located on the banks of roads, in the yards of some rural houses, in public garbage dumps located on the banks of cities and in vacant sites located within urban areas. It adapts to warm, semiwarm and temperate climates and in places where rainfall is around $700 \mathrm{~mm}$ as in the municipalities of Cintalapa and Jiquipilas, to places where rainfall is greater than $3,000 \mathrm{~mm}$ as in the DDR Tapachula, Selva, Pichucalco and Palenque These conditions are consistent with those reported by Moncín (2008), Galeano (1992), Samayoa (2007) and Miranda (2011). Ricinus plants are not observed on agricultural land and the main reason is because producers consider it a weed for their crops. Great phenotypic variability was observed in this species, with plants of green color, red color and clusters of different shape and size. In general, the plants observed are of a height greater than two meters.

Regosol type soils are optimal for the growth of Ricinus communis and with slopes of up to $15 \%$ (Table 1). However, in the field trips it was observed that this species adapts well in different types of soils. No doubt this resistance to biotic and adverse abiotic factors is the result of the natural selection to which this species is exposed year after year.

If we consider that the depletion of fossil fuels, their high cost in international markets and environmental considerations regarding the pollution and release of carbon into the atmosphere, generates an international concern that guides researchers to seek and study species that provide alternative fuels, then the fig tree (Ricinus communis L.) can become very important, because its oil has an infinite number of uses, among which is the production of biodiesel and bioturbocin (biokerosene) as mentioned by Miranda (2012). Therefore, the study of the delimitation of areas with agroecological potential for Ricinus., Allows decision makers in the Agricultural Subsector to plan their cultivation in the state of Chiapas, in order to obtain the raw material (seed), for the extraction of oil and, finally, the production of biofuels, in the areas with optimum potential and, in this way, to increase the economy of the producers in the regions where the low fertility of the soils and the recurrent droughts, are a risk in Agricultural production In addition, producers will make potential use of the soil and in a sustainable way.

The cultivation of fig trees should be established in areas where droughts are recurrent and the soils are of low fertility and with a slope less than and equal to $15 \%$, conditions that exist in the Tuxtla DDR. On the other hand, if Airports and Auxiliary Services (ASA) and CONACYT, continue to issue calls for studies in this species for the production of biofuels (CONACYT, 2012), the areas to establish the cultivation of Ricinus will be those near the airport of Tuxtla Gutiérrez, to facilitate the transport of the raw material (seed), for the extraction of the oil and, it is in this area precisely where there is optimal agroecological potential for cultivation and where INIFAP from 2014 carries out research on evaluation and Variety selection, population density, nitrogen and phosphorus fertilization and weed control in order to generate production 
technologies of Ricinus communis L. Produce a crop where its agroecological requirements are fully covered, without doubt ensures a better yield, with better gains and less environmental deterioration, as indicated by Díaz et al., (2012).

In the case of the Villaflores DDR, where droughts are less recurrent, the potential use of the soil will continue to be corn, beans, sorghum and vegetables, no matter if there are considerable areas with optimal agroecological potential for Ricinus cultivation. The results obtained show the wide agroecological potential that the state of Chiapas has for the cultivation of Ricinus, since the conditions of temperature, altitude, precipitation, slope and soils are adequate.

\section{CONCLUSIONS}

The state of Chiapas has 1,597,939 hectares with optimal agroecological potential for the cultivation of Ricinus communis L. which potentially makes it an ecological niche for the cultivation of this species.

The DDR of the SAGARPA 01 Tuxtla and 04 Villa Flores are the ones with the greatest surface area with high potential for the cultivation of fig trees, at the state level.

Due to its great diversity of adaptation to the climates and soils that exist in the state of Chiapas, it does not represent competition or threat for the sowing of basic crops, and instead it can be an excellent option for the productive reconversion in areas where it no longer thrives the cultivation of corn.

\section{REFERENCES}

CONACYT, 2011. Demandas del sector. Convocatoria 2021, Fondo Sectorial de Investigación para el Desarrollo Aeroportuario y la Navegación Aérea.29 p.

EMBRAPA. 2004. Manejo del cultivo de la higuerilla para una agricultura familiar. EMBRAPA. Brasil. 75 p.

FAO. 1996. Zonificación agroecológica: Guía general. Boletín de suelos. Organización de las Naciones Unidas para la Agricultura y la Alimentación. Roma, Italia. 18 p.

Díaz P., G., Rafael A. Guajardo P., G. Medina G., I. Sánchez C., J. Soria R., J.M, P. Vásquez A., J.A. Quijano C., F. Legorreta P., J.A. Ruiz C., 2012. Potencial productivo de especies agrícolas de importancia socioeconómica en México. Publicación Especial Núm. 8. Campo Experimental Cotaxtla. Centro de Investigación Regional Golfo Centro. INIFAP. 132 p.

Galeano C., G. A. 1992. Caracterización y evaluación de 34 entradas de higuerilla (Ricinus communis L.). Tesis Profesional. Universidad Nacional de Colombia. Medellín. 201 p.

González, A.I.J; J.A Ruiz C; R.A. Martínez P; K F. Byerlee M; L. Mena H y J. A. Osuna G.2002. Determinación del potencial productivo de especies vegetales para el municipio de Rosa Morada, 
Nayarit. Folleto de investigación No.11 Instituto Nacional de Investigaciones Forestales, Agrícolas y pecuarias. Campo Experimental Santiago Ixcuintla. Mexico.66 pp.

INEGI, 2009. VIII Censo Agrícola, Ganadero y Forestal del estado de Chiapas. Dirección Regional Sur. Instituto Nacional de Estadística y Geográfica. México. 301 p.

INEGI, 2002. Carta de uso actual del suelo y vegetación, "serie III. Instituto Nacional de Estadística y Geográfica. México. 2p.

INEGI, 1993.Carta Edafológica, escala 1:250 000. Tuxtla Gutiérrez. Segunda impresión. Aguascalientes, Ags., México. 23 p.

López L., A; A.D. Báez G; J A. Ruiz C y G. Medina G. 2009. Caracterización climática y Edáfica del área de abastecimiento del ingenio Pujiltic, Chiapas. 1ra. Edición. Instituto Nacional de Investigaciones Forestales, Agrícolas y Pecuarias. Campo Experimental Centro de Chiapas. Publicación Especial Numero 1. México. 48 PP.

Miranda R. B.E. 2011. Evaluación del comportamiento y adaptación de 19 accesiones de higuerilla (Ricinus communis L.) procedentes de cuatro departamentos en Pucallpa. Perú. Tesis de Licenciatura. Facultad de Ciencias Agropecuarias. Esc. Profesional de Agronomía. Universidad Nacional de Ucayali, Perú. 160 p.

Moncin M. Del Mar San Miguel. 2008. Instituto Universitario Dexeus, Servicio de Alergia e inmunológica Clínica Ricinus communis. 12 p.

Reynoso S., R; López L., A.; López B., W.; y Ruiz C., J, A. áreas potenciales para el cultivo del Agave (Agave americana L.) en la Meseta Comiteca, Chiapas. INIFAP, CIRPAS, CECECH. Folleto técnico No. 13.65 p.

Ruiz C., J.A., I.J. Gonzalez, C. Ortiz, H.E. Flores L., R.A. Martínez y K.F. Byerly. 1999. Requerimientos agroecológicos de cultivos. Libro técnico No. 3. INIFAP - CIRPAC. Ed. Conexión Gráfica. Guadalajara, Jalisco. México. 28 p.

SAMAYOA. M. O. 2007. Manual técnico del Higüerillo. Ministerio de Agricultura y Ganadería El Salvador C. A. Centro Nacional de Tecnología Agropecuaria y Forestal, CENTA. Programa Agroindustria. $17 \mathrm{p}$.

Serrano A., S.V; G. Díaz P.; A. López L., A. M. A. Cano G; A. D. Báez G y E. R. Garrido R. 2006. Estadísticas climatológicas básicas del estado del estado de Chiapas (Periodo 1961-2003). Libro técnico No. 1. Instituto Nacional de Investigaciones Forestales, Agrícolas y Pecuarias. Campo Experimental Centro Chiapas. México. 186. P. 